Check for updates

Cite this: Chem. Sci., 2019, 10, 4469

๑ All publication charges for this article have been paid for by the Royal Society of Chemistry

Received 9th November 2018

Accepted 11th March 2019

DOI: $10.1039 / \mathrm{c} 8 \mathrm{sc} 05006 \mathrm{f}$

rsc.li/chemical-science

\title{
A robust ALD-protected silicon-based hybrid photoelectrode for hydrogen evolution under aqueous conditions $\uparrow$
}

\author{
Soundarrajan Chandrasekaran, ${ }^{\text {ad }}$ Nicolas Kaeffer, (D) $t^{a}$ Laurent Cagnon, ${ }^{b}$ \\ Dmitry Aldakov, (D) ${ }^{c}$ Jennifer Fize, ${ }^{a}$ Guillaume Nonglaton, ${ }^{d}$ François Baleras, ${ }^{d}$ \\ Pascal Mailley ${ }^{d}$ and Vincent Artero (D) *a
}

\begin{abstract}
Hydrogen production through direct sunlight-driven water splitting in photo-electrochemical cells (PECs) is a promising solution for energy sourcing. PECs need to fulfill three criteria: sustainability, cost-effectiveness and stability. Here we report an efficient and stable photocathode platform for $\mathrm{H}_{2}$ evolution based on Earthabundant elements. A p-type silicon surface was protected by atomic layer deposition (ALD) with a $15 \mathrm{~nm}$ $\mathrm{TiO}_{2}$ layer, on top of which a $300 \mathrm{~nm}$ mesoporous $\mathrm{TiO}_{2}$ layer was spin-coated. The cobalt diimine-dioxime molecular catalyst was covalently grafted onto $\mathrm{TiO}_{2}$ through phosphonate anchors and an additional 0.2 $\mathrm{nm}$ ALD- $\mathrm{TiO}_{2}$ layer was applied for stabilization. This assembly catalyzes water reduction into $\mathrm{H}_{2}$ in phosphate buffer $(\mathrm{pH} 7)$ with an onset potential of $+0.47 \mathrm{~V}$ vs. RHE. The resulting current density is -1.3 $\pm 0.1 \mathrm{~mA} \mathrm{~cm}^{-2}$ at $\mathrm{O} \mathrm{V}$ vs. RHE under AM 1.5 solar irradiation, corresponding to a turnover number of 260 per hour of operation and a turnover frequency of $0.071 \mathrm{~s}^{-1}$
\end{abstract}

\section{Introduction}

The production of solar fuels is one of the most promising strategies to shift towards sustainable energy sourcing as this is the only solution allowing massive amounts of renewable energy to be stored in a durable way. In that context, photoelectrochemical water splitting produces hydrogen $\left(\mathrm{H}_{2}\right)$ as a suitable energy vector. ${ }^{1}$ Indeed, the mature fuel-cell technology allows its energy content to be turned back into electrical power on demand, with a good efficiency and in a closed cycle., ${ }^{2,3}$ The major challenge for the development of photoelectrochemical cells (PECs) lies in the cost effective fabrication of photoelectrodes with high solar energy conversion efficiencies and high durability under normal utilization. ${ }^{4}$ Fulfilling these requirements raises important scientific questions regarding mainly the elaboration and the combination of the best performing materials able to harvest light and catalyze $\mathrm{H}_{2}$ evolution.

\footnotetext{
${ }^{a}$ Université Grenoble Alpes, CNRS, CEA, Laboratoire de Chimie et Biologie des Métaux, 17 rue des Martyrs, 38000 Grenoble, France.E-mail: vincent.artero@cea.fr

${ }^{b}$ Université Grenoble Alpes, CNRS, Institut NEEL, UPR2940, 25 rue des Martyrs BP 166, 38000 Grenoble, France

'Université Grenoble Alpes, CNRS, CEA, INAC-SYMMES, 38000 Grenoble, France

${ }^{d}$ Université Grenoble Alpes, CEA-LETI/DTBS, Laboratoire Chimie, Capteurs et Biomatériaux, 17 rue des Martyrs, 38000 Grenoble, France

$\dagger$ Electronic supplementary information (ESI) available. See DOI: 10.1039/c8sc05006f

\$. Present address: Department of Chemistry and Applied Biosciences, Vladimir Prelog Weg 1-5, ETH Zürich, CH-8093 Zürich, Switzerland.
}

Silicon is highly abundant and can be cost-effectively processed for the industrial construction of photovoltaic panels into crystalline silicon, which has a conduction band (CB) energy level of $\sim-0.5 \mathrm{~V} v s$. NHE $(\mathrm{pH}=0)$ and a narrow band-gap of $1.12 \mathrm{eV} .{ }^{5}$ These features make silicon the material of choice among other semiconductors ${ }^{6-9}$ for the fabrication of $\mathrm{H}_{2^{-}}$ evolving photoelectrodes able to harvest solar irradiation over the whole visible spectrum. ${ }^{10,11}$ However, the major drawback of using silicon as a photoelectrode material is its inherent instability under aqueous or aerobic conditions. This issue can nevertheless be overcome by appropriate surface passivation techniques such as pinhole-free oxide coatings achieved by vacuum deposition, ${ }^{12}$ sputtering ${ }^{13}$ or atomic layer deposition (ALD) techniques. ${ }^{14}$

Even though a few materials based on Earth-abundant elements already compete with platinum for $\mathrm{H}_{2}$ evolution over a wide range of $\mathrm{pH}$ values ${ }^{15}$ the best catalyst does not necessarily yield the best photoelectrode when it is interfaced with a visible-light-harvesting semiconductor. ${ }^{16}$ Indeed, it has been shown that the chemical potential of the catalyst needs to electrochemically equilibrate with the quasi Fermi level of electrons in the irradiated semiconductor, ${ }^{17}$ which strongly depends on the way the connection between the semiconductor and the catalyst is achieved. A ground-breaking study has set the use of porous catalyst materials that can adapt their potential through charging/discharging ions from the electrolyte as a way to achieve good efficiency. ${ }^{18}$ Such a feature is present in electrodeposited amorphous catalytic materials but it was hypothesized that the same feature can be reproduced in hybrid 
systems ${ }^{19}$ through the grafting of molecular catalysts onto a porous conducting transparent support, as a mesoscopic film of $\mathrm{TiO}_{2} \cdot{ }^{20,21}$ Such catalysts could be cobaloximes and diiminedioxime cobalt complexes since their immobilization on electrode supports yields hybrid materials efficiently producing $\mathrm{H}_{2}$ from aqueous electrolytes., ${ }^{\mathbf{6 1 0 , 2 2 - 2 5}}$ Some planar and nanostructured silicon photocathodes interfaced with metal or metal sulphide catalysts can produce current densities $>5 \mathrm{~mA} \mathrm{~cm} \mathrm{~cm}^{-2}$ (Table $\mathrm{S} 1 \dagger$ ). In contrast, for molecular catalysts/hydrogenase enzymes, only the use of high performance semiconductors such as $\mathrm{p}-\mathrm{GaP}$ and $\mathrm{p}-\mathrm{InGaP}_{2}$ produces current densities $>1 \mathrm{~mA}$ $\mathrm{cm}^{-2}$ in photocathode constructs (Table S2 $\dagger$ ).

We report here a strategy to fabricate a molecular-engineered silicon photocathode (Fig. 1) alleviating the previously observed drawbacks, producing current densities $>1 \mathrm{~mA} \mathrm{~cm}^{-2}$ and achieving sustained photoelectrochemical $\mathrm{H}_{2}$ evolution in neutral pH under AM 1.5 solar irradiation. To that aim, we combined for the first time ALD protection of a p-Si photocathode and the use of a mesoporous catalytic layer based on $\mathrm{TiO}_{2}$ interfaced with a molecular diimine dioxime cobalt catalyst.

\section{Results and discussion}

The native surface oxide layer of commercial boron-doped ptype silicon (100) wafers (725 $\mu$ m-thick, resistivity 1-50 $\Omega \mathrm{cm}$ ) was removed using hydrofluoric acid (HF) (see the Experimental part for the detailed etching process). Then the p-Si electrodes were rapidly transferred to the chamber of an ALD system. The electrodes were coated with a first layer of $\mathrm{TiO}_{2}$ through $710 \mathrm{ALD}$ cycles performed in continuous mode at $255^{\circ} \mathrm{C}$. Fig. $2 \mathrm{~A}$ shows the top view scanning electron microscopy (SEM) image of this p-Si|ALD-TiO ${ }_{2}$ electrode, revealing a $\mathrm{TiO}_{2}$ layer for the protection of $\mathrm{p}$-Si against corrosion in aqueous electrolytes. The thickness of the $\mathrm{ALD}^{-\mathrm{TiO}_{2}}$ layer measured by ellipsometry was $\sim 15 \mathrm{~nm}$. A second layer of mesoporous $\mathrm{TiO}_{2}$ was then spincoated (SC) on top of the first layer to increase the surface area of the electrode and thus afford higher catalyst loading. Fig. 2B and $\mathrm{C}$ show the top view and cross-sectional SEM images of $\mathrm{p}$ $\mathrm{Si}\left|\mathrm{ALD}-\mathrm{TiO}_{2}\right| \mathrm{SC}^{-} \mathrm{TiO}_{2}$ electrodes, revealing a $\sim 300 \mathrm{~nm}$ thickness for the $\mathrm{SC}-\mathrm{TiO}_{2}$ layer. We selected the diimine-dioxime cobalt complex $\left(\mathbf{C o}_{\mathbf{C 1 1}}\right)$ derivative containing a pendant phosphonic acid anchor as the $\mathrm{H}_{2}$-evolving molecular catalyst. ${ }^{26}$ Soaking the
p-Si|ALD- $\mathrm{TiO}_{2} \mid \mathrm{SC}-\mathrm{TiO}_{2}$ electrodes in a methanolic solution of $\mathbf{C o}_{\mathbf{C 1 1}}$ results in the straightforward immobilization of the complex. The grafting occurs through the formation of a mixed organic-inorganic phosphonate linkage, ${ }^{27}$ as evidenced by electrochemistry, X-ray photoelectron spectroscopy (XPS) and infrared spectroscopy (see below). To further stabilize the catalyst anchoring against hydrolysis during long term operation in aqueous electrolytes, we specifically undertook a second ALD process, inspired by the "Mummy" strategy. ${ }^{28}$ In this process, an ultra-thin overlayer of $\mathrm{TiO}_{2}$ is deposited at the mesoporous $\mathbf{C o}_{\mathbf{C 1 1}} \mathbf{P}^{- \text {modified }} \mathrm{SC}-\mathrm{TiO}_{2}$ interface to shield the catalyst-surface linkage. ${ }^{28}$ We thus performed 10 ALD cycles in a $5 \mathrm{~s}$ exposure mode at $150{ }^{\circ} \mathrm{C}$. The low deposition temperature was used to avoid potential degradation of the molecular structure of the catalyst while the selected exposure mode ensured that the $\sim 0.2 \mathrm{~nm}$ thick overlayer is uniformly deposited within the whole mesoporous layer of $\mathbf{C o}_{\mathbf{C 1 1}}$-modified $\mathrm{TiO}_{2}$.

Fig. 3 shows the XPS spectra of the Co $2 \mathrm{p}$ core region of $\mathrm{p}$ $\mathrm{Si}\left|\mathrm{ALD}^{-\mathrm{TiO}_{2}}\right| \mathrm{SC}^{-\mathrm{TiO}_{2}} \mid \mathbf{C o}_{\mathbf{C 1 1 P}}$ (black trace) and p-Si|ALD-TiO ${ }_{2}$ $\left|\mathrm{SC}-\mathrm{TiO}_{2}\right| \mathbf{C o}_{\mathbf{C 1 1}} \mid \mathrm{ALD}-\mathrm{TiO}_{2}$ (red trace) electrodes. The peaks observed at 795.4 and $780.2 \mathrm{eV}$ correspond to Co $2 \mathrm{p}_{1 / 2}$ and $2 \mathrm{p}_{3 / 2}$ core levels, respectively. The binding energies are similar to those previously reported for the same catalytic moiety bound to carbon nanotubes, NiO or ITO..$^{22,25,26}$ The fact that the binding energies of the Co $2 \mathrm{p}$ peaks are not modified upon coating strongly suggests that this overlayer did not degrade the molecular structure of the $\mathbf{C o}_{\mathbf{C 1 1}}$ catalyst in p-Si|ALD-TiO ${ }_{2} \mid \mathrm{SC}$ $\mathrm{TiO}_{2}\left|\mathbf{C o}_{\mathbf{C 1 1}}\right| \mathrm{ALD}-\mathrm{TiO}_{2}$ electrodes.

A Fourier transform infrared (FTIR) spectrum was measured on the $\mathbf{C o}_{\mathbf{C 1 1}}$-modified $\mathrm{TiO}_{2}$ material scratched from a p$\mathrm{Si}\left|\mathrm{ALD}-\mathrm{TiO}_{2}\right| \mathrm{SC}^{-\mathrm{TiO}_{2}}\left|\mathbf{C o}_{\mathbf{C 1 1 P}}\right| \mathrm{ALD}-\mathrm{TiO}_{2}$ electrode and sampled as a $\mathrm{KBr}$ pellet. Fig. 4 compares the FTIR spectrum of this material (red trace) with that of the $\mathbf{C o}_{\mathbf{C 1 1 P}}$ molecular catalyst (black trace). Signals corresponding to the stretching frequencies of the oxime, imine and $\mathrm{C}-\mathrm{C}$ bond in the imine-oxime moieties are found almost unchanged in both spectra at 1140/ 1146, 1519/1514 and $1251 \mathrm{~cm}^{-1}$, respectively (assignments made by comparison with the related cobaloxime compounds following ref. 29). The broad peak at $\sim 1625 \mathrm{~cm}^{-1}$ observed for the $\mathrm{p}$-Si $\left|\mathrm{ALD}-\mathrm{TiO}_{2}\right| \mathrm{SC}-\mathrm{TiO}_{2}\left|\mathbf{C o}_{\mathbf{C 1 1}}\right| \mathrm{ALD}-\mathrm{TiO}_{2}$ electrode (red trace) corresponds to the bending vibration band of the hydrogen-bonded adsorbed water on unmodified $\mathrm{TiO}_{2}$ (blue

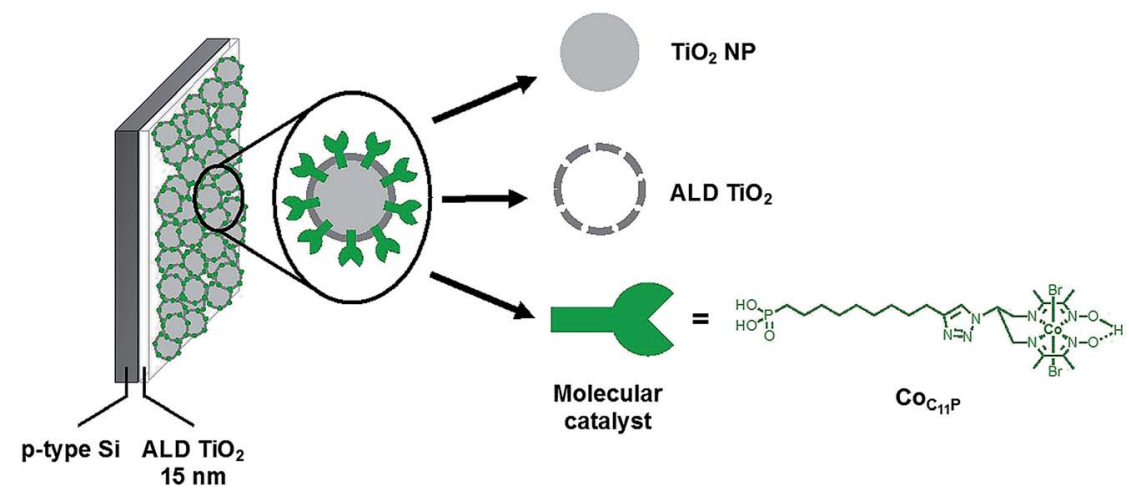

Fig. 1 Molecular-engineered silicon photocathode for $\mathrm{H}_{2}$-evolution. 

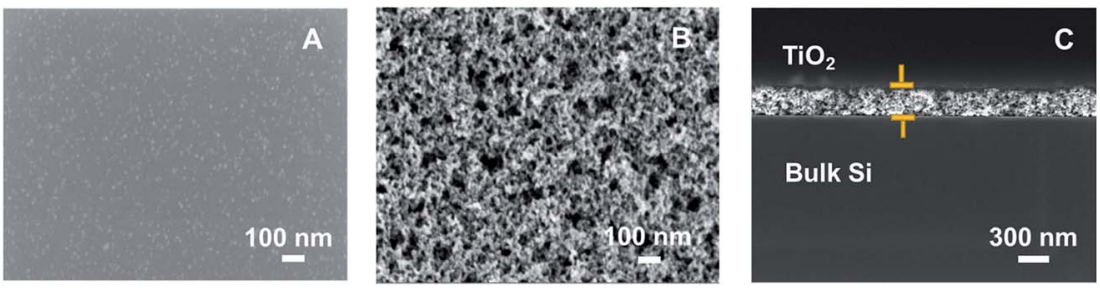

Fig. $2 \mathrm{SEM}$ images of $\mathrm{TiO}_{2}$ layers on $\mathrm{p}-\mathrm{Si}$ : ALD-TiO 2 (top view) (A) and ALD-TiO $/ \mathrm{SC}-\mathrm{TiO}_{2}$ top view (B) and cross-sectional view (C).

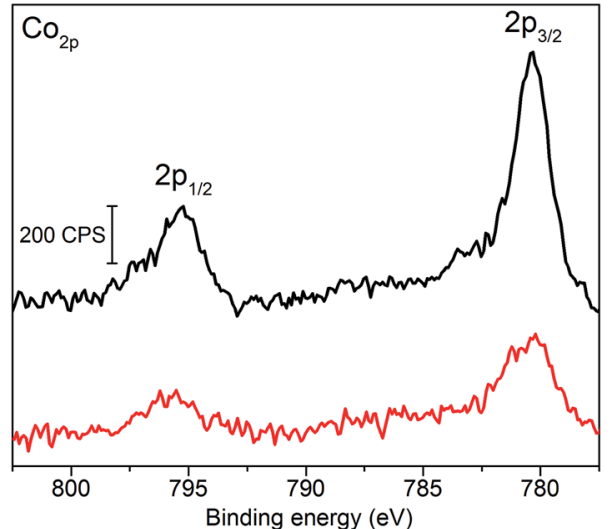

Fig. 3 X-ray photoelectron spectra of the Co $2 p$ core region of the $p$ $\mathrm{Si}\left|\mathrm{ALD}-\mathrm{TiO}_{2}\right| \mathrm{SC}-\mathrm{TiO}_{2} \mid \mathrm{Co}_{\mathrm{C} 11 \mathrm{P}}$ electrode (black trace) and $\mathrm{p}-\mathrm{Si} \mid \mathrm{ALD}$ $\mathrm{TiO}_{2}\left|\mathrm{SC}-\mathrm{TiO}_{2}\right| \mathrm{Co}_{\mathrm{C} 11 \mathrm{P}} \mid \mathrm{ALD}-\mathrm{TiO}_{2}$ electrode (red trace).

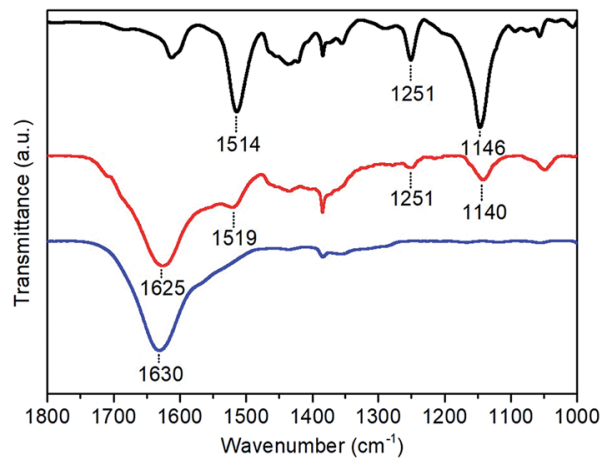

Fig. 4 FTIR spectra of the $\mathrm{Co}_{\mathrm{c} 11 \mathrm{P}}$ molecular catalyst as synthesized (black trace), $\mathrm{p}-\mathrm{Si}\left|\mathrm{ALD}-\mathrm{TiO}_{2}\right| \mathrm{SC}-\mathrm{TiO}_{2}\left|\mathrm{Co}_{\mathrm{C} 11 \mathrm{P}}\right| \mathrm{ALD}-\mathrm{TiO}_{2}$ electrode (red trace) and unmodified $\mathrm{TiO}_{2}$ (blue trace).

trace, $\left.1630 \mathrm{~cm}^{-1}\right) \cdot \cdot^{30,31}$ This analysis further confirmed that the final $10 \mathrm{ALD}$ cycles for $\mathrm{TiO}_{2}$ deposition at $150^{\circ} \mathrm{C}$ did not degrade the molecular structure of the $\mathbf{C o}_{\mathbf{C 1 1}}$ catalyst.

$\mathbf{C o}_{\mathbf{C 1 1 P}}$ loading on the p-Si $\left|\mathrm{ALD}-\mathrm{TiO}_{2}\right| \mathrm{SC}-\mathrm{TiO}_{2}\left|\mathbf{C o}_{\mathbf{C 1 1 P}}\right| \mathrm{ALD}-$ $\mathrm{TiO}_{2}$ electrode was quantified by inductively coupled plasma atomic emission spectrometry (ICP-AES) after digestion of the $\mathrm{ALD}^{-\mathrm{TiO}_{2}}\left|\mathrm{SC}_{-\mathrm{TiO}}\right| \mathbf{C o}_{\mathbf{C 1 1 P}} \mid \mathrm{ALD}-\mathrm{TiO}_{2}$ layer in sulfuric acid. ICPAES analysis indicated a Co loading of $67.4 \pm 0.42 \mathrm{nmol} \mathrm{cm}^{-2}$. We, however, note that only a fraction of the grafted catalysts may be electrochemically addressable, as reported previously for similar catalyst-modified mesoporous conducting metal oxide electrodes. ${ }^{9,26}$
The photo-electrocatalytic properties of the $\mathrm{p}$-Si|ALD-TiO ${ }_{2}$ $\left|\mathrm{SC}^{-\mathrm{TiO}_{2}}\right| \mathbf{C o}_{\mathbf{C 1 1 P}} \mid \mathrm{ALD}-\mathrm{TiO}_{2}$ electrode for $\mathrm{H}_{2}$ evolution were assessed in degassed $1 \mathrm{M}$ phosphate buffer $(\mathrm{pH} 7)$ under solar AM 1.5 irradiation in a three-electrode system. Negligible current densities were observed during linear sweep voltammetry (LSV, $10 \mathrm{mV} \mathrm{s}^{-1}$ ) under dark conditions for all the fabricated photocathodes (Fig. 5). Under illumination (1 sun $\mathrm{AM} 1.5)$, the LSV of the p-Si $\left|\mathrm{ALD}-\mathrm{TiO}_{2}\right| \mathrm{SC}^{-\mathrm{TiO}_{2}}\left|\mathbf{C o}_{\mathbf{C 1 1 P}}\right| \mathrm{ALD}-\mathrm{TiO}_{2}$ electrode (Fig. 5, red trace) displays a current density of -1.25 $\mathrm{mA} \mathrm{cm}{ }^{-2}$ at $0 \mathrm{~V} v s$. RHE and an onset photocurrent potential of $+0.47 \mathrm{~V} v s$. RHE (fill factor of 0.17). In comparison, the p-Si|ALD$\mathrm{TiO}_{2}\left|\mathrm{SC}-\mathrm{TiO}_{2}\right| \mathbf{C o}_{\mathbf{C 1 1}}$ electrode without the ALD-TiO ${ }_{2}$ overlayer displays much lower performances, with a threefold lower $(-0.5$ $\mathrm{mA} \mathrm{cm}{ }^{-2}$ ) current density at $0 \mathrm{~V} v s$. RHE and an onset photocurrent potential of $+0.09 \mathrm{~V} v s$. RHE (Fig. 5 , black trace). In both cases, the photovoltage provided at the $\mathrm{p}-\mathrm{Si} / \mathrm{TiO}_{2}$ results in catalysis, occurring from potentials significantly more positive than the redox potential of the $\mathrm{Co}^{\mathrm{II}} / \mathrm{Co}^{\mathrm{I}}$ couple observed at $\sim 0 \mathrm{~V}$ vs. RHE for $\mathbf{C o}_{\mathbf{C 1 1}}$-modified $\mathrm{TiO}_{2}$ electrodes deposited onto FTO (see Fig. S1†). The higher current density displayed by the $\mathrm{p}$-Si $\left|\mathrm{ALD}-\mathrm{TiO}_{2}\right| \mathrm{SC}_{-} \mathrm{TiO}_{2}\left|\mathbf{C o}_{\mathbf{C 1 1}}\right| \mathrm{ALD}-\mathrm{TiO}_{2}$ electrode compared to the same construction incorporating decylphosphonic acid $\mathbf{C}_{\mathbf{1 0 p}}$, as a surrogate reproducing surface modification through phosphonate binding, clearly evidences the role of $\mathbf{C o}_{\mathbf{C 1 1 P}}$ in catalyzing $\mathrm{H}_{2}$ evolution (Fig. $\mathrm{S} 2 \dagger$ ). The current density displayed by the p-Si $\mid$ ALD-TiO ${ }_{2}\left|\mathrm{SC}_{\mathrm{TiO}}\right| \mathbf{C o}_{\mathbf{C 1 1 P}} \mid \mathrm{ALD}-\mathrm{TiO}_{2}$ photocathode is one order of magnitude higher than that of a similar hybrid

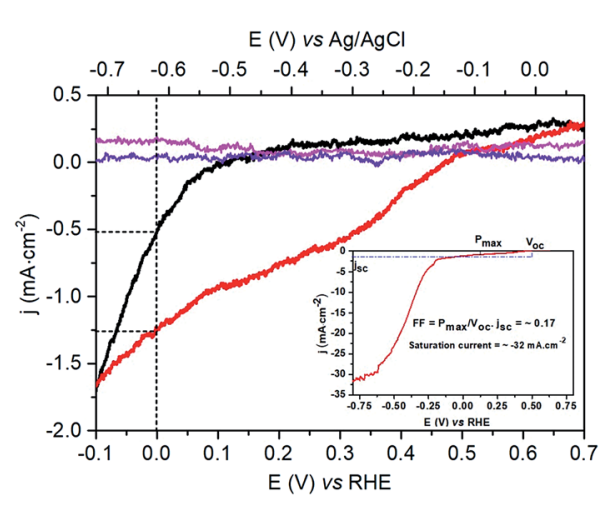

Fig. $5 \mathrm{LSV}\left(10 \mathrm{mV} \mathrm{s}{ }^{-1}\right)$ of the $\mathrm{p}-\mathrm{Si}\left|\mathrm{ALD}-\mathrm{TiO}_{2}\right| \mathrm{SC}-\mathrm{TiO}_{2} \mid \mathrm{Co}_{\mathrm{C} 11 \mathrm{P}}$ electrode (magenta, resp. black trace) and $\mathrm{p}-\mathrm{Si}\left|\mathrm{ALD}-\mathrm{TiO}_{2}\right| \mathrm{SC}-\mathrm{TiO}_{2}\left|\mathrm{Co}_{\mathrm{C} 11 \mathrm{P}}\right| \mathrm{ALD}-$ $\mathrm{TiO}_{2}$ electrode (violet, resp. red trace) in $1 \mathrm{M}$ phosphate buffer $(\mathrm{pH}$ 7) under dark conditions, respectively, one sun irradiation. The inset shows the $\mathrm{p}-\mathrm{Si}\left|\mathrm{ALD}-\mathrm{TiO}_{2}\right| \mathrm{SC}-\mathrm{TiO}_{2}\left|\mathrm{Co}_{\mathrm{C} 11 \mathrm{P}}\right| \mathrm{ALD}-\mathrm{TiO}_{2}$ electrode (red trace) at more negative potentials and the calculated fill factor (FF). 
construction without $\mathrm{ALD}-\mathrm{TiO}_{2}$ layers $\left(\mathrm{p}-\mathrm{Si}\left|\mathrm{mesoTiO}_{2}\right| \mathbf{N i P}\right){ }^{\mathbf{1 0}}$ At the same time the onset potential is shifted $350 \mathrm{mV}$ more positive. The significantly improved performance of the electrode functionalized with the 10 cycle $\mathrm{ALD}-\mathrm{TiO}_{2}$ overlayer confirms that such an overlayer enables the sequestering of the Co $\mathbf{C}_{\mathbf{C 1 1}}$ molecular catalyst within the mesoporous $\mathrm{TiO}_{2}$ layer where it can mediate $\mathrm{H}_{2}$ evolution.

The superior behavior fostered by the $\mathrm{ALD}-\mathrm{TiO}_{2}$ overlayer was further supported by chronoamperometric measurements performed for 1 hour at $0 \mathrm{~V} v s$. RHE under similar conditions (Fig. 6). ${ }^{32}$ An initial decay of current, also observed in catalystfree electrodes (Fig. S3†), might originate from the charging behavior at the silicon/ $/ \mathrm{TiO}_{2}$ interface and/or within the n-type $\mathrm{TiO}_{2}$ semiconductor caused by the sudden illumination. Then, both electrodes exhibited stable current densities of the same magnitude as that measured during LSV experiments, i.e. -0.5 and $-1.3 \mathrm{~mA} \mathrm{~cm}{ }^{-2}$ for $\mathrm{p}-\mathrm{Si}\left|\mathrm{ALD}-\mathrm{TiO}_{2}\right| \mathrm{SC}-\mathrm{TiO}_{2} \mid \mathbf{C o}_{\mathbf{C 1 1 P}}$ and the overcoated p-Si $\left|\mathrm{ALD}^{-\mathrm{TiO}_{2}}\right| \mathrm{SC}-\mathrm{SiO}_{2}\left|\mathbf{C o}_{\mathbf{C 1 1 P}}\right| \mathrm{ALD}-\mathrm{TiO}_{2}$ electrodes, respectively (Fig. 6, black and red traces, respectively). The chronoamperometric trace of the p-Si|ALD-TiO ${ }_{2} \mid \mathrm{SC}-\mathrm{TiO}_{2}$ $\left|\mathbf{C o}_{\mathbf{C 1 1 P}}\right| \mathrm{ALD}-\mathrm{TiO}_{2}$ electrode shows staggered variations due to the intermittent release of $\mathrm{H}_{2}$ bubbles from the electrode surface. Gas chromatography analysis quantified the production of $17.3 \mu \mathrm{mol} \mathrm{cm}{ }^{-2}$ of $\mathrm{H}_{2}$, which evolved concomitantly with the passage of $3.96 \mathrm{C} \mathrm{cm}^{-2}$ through the $\mathrm{p}-\mathrm{Si}\left|\mathrm{ALD}-\mathrm{TiO}_{2}\right| \mathrm{SC}$ $\mathrm{TiO}_{2}\left|\mathbf{C o}_{\mathbf{C 1 1 p}}\right| \mathrm{ALD}-\mathrm{TiO}_{2}$ electrode, yielding a faradaic efficiency of $84 \%$. With these data and the catalyst loading determined from ICP-AES, a turnover number (TON) of 260 and a turnover frequency (TOF) of $0.071 \mathrm{~s}^{-1}$ were calculated.

We note that higher current densities are observed at more negative potentials (see the inset in Fig. 5) with a second photoinduced process starting at $-0.25 \mathrm{~V} v s$. RHE. This second process likely corresponds to $\mathrm{H}_{2}$ evolution directly mediated at the surface of $\mathrm{TiO}_{2}$ as it is also observed for the p-Si|ALD$\mathrm{TiO}_{2} \mid \mathrm{SC}-\mathrm{TiO}_{2}$ electrode at higher negative potential (Fig. S4 $\dagger$ ). Possibly the construction described here does not allow for sufficient catalyst loading (based on the intrinsic turnover frequency of each molecular catalyst) to sustain such high

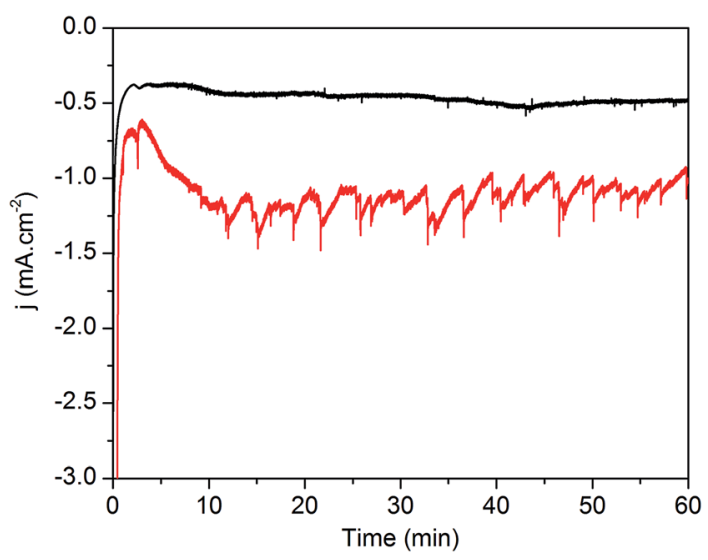

Fig. 6 Chronoamperometric profiles of the p-Si|ALD- $\mathrm{TiO}_{2} \mid \mathrm{SC}-\mathrm{TiO}_{2}-$ $\mid \mathrm{Co}_{\mathrm{C} 11 \mathrm{P}}$ electrode (black trace) and $\mathrm{p}-\mathrm{Si}\left|\mathrm{ALD}-\mathrm{TiO}_{2}\right| \mathrm{SC}-\mathrm{TiO}_{2} \mid \mathrm{Co}_{\mathrm{C} 11 \mathrm{P}}-$ |ALD-TiO 2 electrode (red trace) in $1 \mathrm{M}$ phosphate buffer $(\mathrm{pH}$ 7) recorded at $\mathrm{O} V \mathrm{vs}$. RHE under one sun irradiation. current densities. Alternatively, the electronic coupling between the Si wafer and the $\mathrm{TiO}_{2}$ layers may not be optimal to allow the catalyst layer to equilibrate with the conduction band of $\mathrm{Si}$.

We also investigated the behaviour of the p-Si|ALD-TiO ${ }_{2} \mid \mathrm{SC}-$ $\mathrm{TiO}_{2}\left|\mathbf{C o}_{\mathbf{C 1 1 P}}\right| \mathrm{ALD}-\mathrm{TiO}_{2}$ electrodes in $0.1 \mathrm{M} \mathrm{NaOH}(\mathrm{pH} 13$ ) (Fig. S5 $\dagger$ ). From LSV measurements, the current density and onset photocurrent potential were measured as $-1 \mathrm{~mA} \mathrm{~cm}^{-2}$ at $0 \mathrm{~V}$ vs. RHE and +0.53 V vs. RHE under solar AM 1.5 illumination, respectively. These figures indicate good $\mathrm{H}_{2}$-evolution properties of the $\mathbf{C o}_{\mathbf{C 1 1 P}}$ catalyst in basic aqueous electrolyte, in line with Turner's report on the catalytic activity of cobaloximes under similar conditions. ${ }^{6}$ Current densities similar to those observed in LSV were sustained during chronoamperometric measurements $\left(0 \mathrm{~V}\right.$ vs. RHE) at the $\mathrm{p}$-Si $\left|\mathrm{ALD}-\mathrm{TiO}_{2}\right| \mathrm{SC}-\mathrm{TiO}_{2}$ $\left|\mathbf{C o}_{\mathbf{C 1 1 P}}\right|$ ALD-TiO ${ }_{2}$ electrode in $0.1 \mathrm{M} \mathrm{NaOH}$ (pH 13) for a period of one hour under AM 1.5 solar irradiation (Fig. S6 $\dagger$ ), yielding a faradaic efficiency of $83 \%$. TON and TOF were calculated to be 215 and $0.06 \mathrm{~s}^{-1}$, respectively, based on the catalytic loading determined through ICP-AES. XPS analysis of the Co $2 \mathrm{p}$ core region (Fig. S7 $\dagger$ ) carried out at the end of this chronoamperometry experiment supports the presence of the retained $\mathbf{C o}_{\mathbf{C 1 1 P}}$ molecular catalyst on the p-Si|ALD-TiO ${ }_{2} \mid \mathrm{SC}$ $\mathrm{TiO}_{2}\left|\mathbf{C o}_{\mathbf{C 1 1 P}}\right| \mathrm{ALD}-\mathrm{TiO}_{2}$ electrode, with a Co $2 \mathrm{p}_{3 / 2}$ peak at 780.2 $\mathrm{eV}$, similar to that in Fig. 3, whereas alteration of the Co complex would result in a shoulder peak around $782 \mathrm{eV}{ }^{6,33}$ The noisiness of this feature indicates that the complex is present at the very surface of the mesoporous $\mathrm{TiO}_{2}$ layer with a decreased concentration compared to the as-prepared sample. By contrast, a system based on a similar diimine-dioxime catalyst attached on $\mathrm{TiO}_{2}$ shows full disappearance of the XPS Co $2 \mathrm{p}_{3 / 2}$ signature after activity. ${ }^{10}$ Retention of the Co $2 \mathrm{p}_{3 / 2}$ XPS binding energy after activity is another indication that the ALD-strategy is effective in stabilizing the grafting of the molecular catalyst during turn-over. These data show for the first time the versatility and stability of the Co $\mathbf{O}_{\mathbf{C 1 1}}$ molecular catalyst and phosphonate anchor, respectively, which is operative over a wide range of $\mathrm{pH}$ values, paralleling a report on cobaloximes with carboxylate anchors by Turner and coworkers. ${ }^{6}$ Furthermore, working of photocathodes in basic aqueous electrolytes is of great interest since that would help to tether them with $\mathrm{TiO}_{2}$ based photoanodes in a tandem cell configuration for unbiased water splitting.

In both cases, relatively high photocurrent densities measured at $0 \mathrm{~V} v s$. RHE result from the combination of an ALDcoated compact $\mathrm{TiO}_{2}$ underlayer protecting $\mathrm{p}$-Si from corrosion, a mesoporous $\mathrm{TiO}_{2}$ layer allowing for high catalytic loading, and a second ALD-coated compact ultrathin $\mathrm{TiO}_{2}$ overlayer stabilizing the anchorage of the molecular catalyst onto the mesoporous layer. Our control experiments (Fig. S3†) demonstrate that all three components are crucial to achieve efficiency and stability: (i) the presence of a thin $\mathrm{TiO}_{2}$ protective layer allows generation of photocurrent in the $\mathrm{mA} \mathrm{cm}^{-2}$ range for photoelectrodes stored in ambient atmosphere for days, (ii) the SC mesoporous $\mathrm{TiO}_{2}$ allows a 10 -fold increase of the current density compared to a flat $\mathrm{ALD}-\mathrm{TiO}_{2}$ surface (compare red and orange curves in Fig. S3b $\dagger$ ), and (iii) the presence of an ALD$\mathrm{TiO}_{2}$ overlayer results in a sustained photocurrent at its 
nominal value measured during LSV. This result is particularly remarkable since the non-stabilized grafting of a similar diimine-dioxime cobalt catalyst led to rapid leaching of the catalyst from the mesoporous $\mathrm{TiO}_{2}$ layer $(30 \mathrm{~min},<2$ TONs achieved), ${ }^{10}$ while the ALD-coated $\mathrm{TiO}_{2}$ overlayer of this study allowed a sustained TOF (260 TONs achieved within $1 \mathrm{~h}$ with stable current density) for $\mathrm{H}_{2}$ evolution by the molecular catalyst. With such an optimized platform we offer the possibility of using cost-effective silicon wafers for the preparation of hybrid photocathodes displaying performances previously restricted to expensive III-V semiconductors such as $\mathrm{GaP}^{7,8}$ or $\mathrm{GaInP}_{2}{ }^{6}$

\section{Conclusion}

We successfully designed a stable photocathode platform that unlocks the exploitation of cost-effective and technology-ready silicon wafers for the construction of robust photocathodes exclusively based on Earth-abundant elements, as an asset for sustainability. ALD and sol-gel coating techniques, which we used in our strategy, are currently deployed for various industrial applications, en route for the future scaling up of the production of such photoelectrodes. The assets of this photocathode architecture are resistance to corrosion, high catalyst loading and retention of the molecular structure of the catalyst on the electrode surface. These assets result in a platform suitable to anchor various molecular catalysts onto inorganic semiconductors in future research on (photoelectro)catalysis. Reaching the current density displayed by high-performing semiconductors by improving the loading densities in molecular catalysts at hybrid electrodes is currently being investigated in our laboratory and could benefit from the hierarchical inverse opal $\mathrm{TiO}_{2}$ structures recently developed for photoelectrochemical biological systems. ${ }^{34}$

\section{Experimental}

\section{Chemicals}

Hydrofluoric acid (HF, 48\%), solvents and starting materials were purchased from Sigma Aldrich. Ultrapure nitric acid (65\%) for ICP-AES analysis was purchased from Chem-Lab. Co. $\mathbf{C}_{\mathbf{C 1 1}}$ was prepared as previously described. ${ }^{26}$ Decylphosphonic acid $\left(\mathbf{C}_{\mathbf{1 0 P}}\right)$ was purchased from Sigma-Aldrich.

\section{ALD of $\mathrm{TiO}_{2}$ on the silicon surface (p-Si|ALD-TiO}

Boron doped p-type silicon with a resistivity of 1-50 ohm cm, orientation 100, thickness $725 \mu \mathrm{m}$ and diameter $200 \mathrm{~mm}$ was bought from MEMC. The silicon was cut into $0.5 \times 0.5 \mathrm{~cm}$ pieces and etched with $1: 1 \mathrm{HF}$ : ethanol mixture for $10 \mathrm{~min}$. It was then stored in an argon degassed heptane solution and dried under argon before transferring into the ALD chamber. $\mathrm{TiO}_{2}$ was deposited using an ALD system (Savannah 100 ALD system, Cambridge Nano Tech Inc.) with a precursor temperature at 95 ${ }^{\circ} \mathrm{C}$, pump line temperature at $150{ }^{\circ} \mathrm{C}$ and sample chamber temperature at $255{ }^{\circ} \mathrm{C}$ in continuous mode for 710 cycles with a nitrogen flow of $5 \mathrm{sccm}$. The precursors used for $\mathrm{TiO}_{2}$ deposition were titanium(IV) isopropoxide (TTIP) purchased from
Strem Chemicals Inc. and water as sources for titanium and oxygen, respectively. A cycle typically comprised a 0.5 s TTIP pulse and a $0.02 \mathrm{~s}$ water pulse with a $5 \mathrm{~s}$ purging time in between.

\section{$\mathrm{SC}$ of mesoporous $\mathrm{TiO}_{2}$ on the $\mathrm{ALD}-\mathrm{TiO}_{2}$ deposited silicon surface (p-Si|ALD-TiO ${ }_{2} \mid \mathrm{SC}_{\mathbf{T}} \mathrm{TiO}_{2}$ )}

A suspension of $\mathrm{TiO}_{2}$ anatase nanoparticles of size 15-20 nm (Ti-Nanoxide T300/SC, Solaronix) was spin-coated on ALD-TiO deposited on silicon (polished side). The spin-coating was carried out at $5000 \mathrm{rpm}$ for $30 \mathrm{~s}$, with an acceleration of 2000 $\mathrm{rpm} \mathrm{s}^{-1}$. The coated electrodes were then thermally treated at $475{ }^{\circ} \mathrm{C}$ for $30 \mathrm{~min}$ in a tubular furnace under an argon flow.

Immobilization of the $\mathrm{Co}_{\mathrm{C} 11 \mathrm{P}}$ molecular catalyst and $\mathrm{C}_{10 \mathrm{P}}$ molecular anchor on the $\mathrm{TiO}_{2}$ coated silicon surface (p-

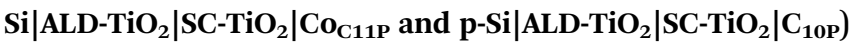

A saturated solution of $\mathbf{C o}_{\mathbf{C 1 1 P}}$ molecular catalyst ${ }^{\mathbf{2 6}}$ was prepared with methanol. Silicon substrates coated with $\mathrm{ALD}^{-\mathrm{TiO}}{ }_{2}$ and mesoporous $\mathrm{SC}^{-\mathrm{TiO}_{2}}$ were soaked overnight in the catalyst solution. The substrates were then washed with methanol before further modification. A similar procedure was followed to sensitize the electrode with the $\mathbf{C}_{\mathbf{1 0 p}}$ molecular anchors.

\section{ALD-TiO ${ }_{2}$ deposition on the $\mathrm{Co}_{\mathrm{C11P}}$ molecular catalyst immobilized $\mathrm{TiO}_{2}$ coated silicon surface (p-Si|ALD-TiO ${ }_{2} \mid \mathrm{SC}-$ $\left.\mathrm{TiO}_{2}\left|\mathrm{Co}_{\mathrm{C11P}}\right| \mathbf{A L D}-\mathrm{TiO}_{2}\right)$}

Co $\mathbf{C}_{\text {C11 }}$-functionalized $\mathrm{TiO}_{2}$-modified silicon electrodes were coated with 10 cycles of $\mathrm{ALD}-\mathrm{TiO}_{2}$. ALD was performed in exposure mode with an exposure time of $5 \mathrm{~s}$. During the exposure, pumping on the chamber is stopped in order to allow time for the precursors to diffuse in the mesoporous $\mathrm{TiO}_{2}$ layer. Except for the temperature of the deposition chamber which was decreased from $255{ }^{\circ} \mathrm{C}$ to $150{ }^{\circ} \mathrm{C}$ to avoid degradation of the catalysts, the other parameters (temperature, nitrogen flow, pulse duration and purging time) were kept the same as in continuous mode.

\section{Preparation of $\mathrm{TiO}_{2}-\mathrm{Co}_{\mathrm{C11P}}$ electrodes}

Screen-printed $\mathrm{TiO}_{2}$ substrates were purchased from Solaronix. The electrodes were sintered under atmospheric conditions in a Harry Gestigkeit flat furnace operated with a Detflef Gestigkeit-Programmer PR5 control board programmed with the following temperature ramp: R.T. to $450{ }^{\circ} \mathrm{C}$ (30 $\left.\mathrm{min}\right), 30 \mathrm{~min}$ at $450{ }^{\circ} \mathrm{C}$. The thickness of the $\mathrm{TiO}_{2}$ layer is $c a .600 \mathrm{~nm}$. The substrates were cooled to $c a .90{ }^{\circ} \mathrm{C}$ and introduced in PTFE boxes containing $10 \mathrm{~mL}$ of a $0.5 \mathrm{mM}$ methanolic solution with Co $\mathbf{o}_{\mathbf{C 1 1}}(5 \mu \mathrm{mol})$. The boxes were closed and the content was stirred for $24 \mathrm{~h}$ on an orbital stirring plate. The electrodes were removed from the solution, washed by dipping them in pristine methanol for 10 min under orbital stirring and dried with $\mathrm{N}_{2}$, to yield the decorated $\mathrm{TiO}_{2} / \mathbf{C o}_{\mathbf{C 1 1}}$ electrodes.

\section{Instrumental characterization techniques}

A Zeiss Ultra+ instrument was used for SEM imaging of ALD$\mathrm{TiO}_{2}$ and mesoporous $\mathrm{SC}-\mathrm{TiO}_{2}$ in In-Lens mode at accelerating voltages of $20 \mathrm{kV}$ and $2 \mathrm{kV}$, respectively. 
An ellipsometer (M 2000 model) from J. A. Woollam Co., In. was used to measure the thickness of the $\mathrm{ALD}-\mathrm{TiO}_{2}$ substrate, using the CompleteEASE software (V4.72). It was used in the "offsample" configuration with an incident angle of attack of $75^{\circ}$ with respect to the film plane normal, and the light wavelength was scanned between $200 \mathrm{~nm}$ and $1700 \mathrm{~nm}$. The obtained data were fitted with the CompleteEASE software (V4.72). A typical example of the recorded spectrum and its fit are displayed in Fig. S8. $\dagger$

FTIR spectra were recorded on a Perkin-Elmer Spectrum 100 spectrometer. The spectra were collected over 64 scans, with a resolution of $1 \mathrm{~cm}^{-1}$ and background corrected with an ambient atmosphere spectrum. Spectra of the samples were recorded and analyzed using SPECTRUM version 10.5.2 software, in the range of $1000-2000 \mathrm{~cm}^{-1}$. The powdered samples were mixed in $\mathrm{KBr}$ and pressed to form pellets. Typically, the pellets were made of the scratched overlayer of the electrode (4 $\mathrm{cm}^{2}$ ) mixed with $100 \mathrm{mg}$ of $\mathrm{KBr}$.

XPS analyses were carried out with a Versa Probe II spectrometer (ULVAC-PHI) equipped with a monochromated $\mathrm{Al} \mathrm{K} \alpha$ source $(h \nu=1486.6 \mathrm{eV})$. The core level peaks were recorded with a constant pass energy of $23.3 \mathrm{eV}$. The XPS spectra were fitted with CasaXPS 2.3.15 software using Shirley background and a combination of Gaussian (70\%) and Lorentzian (30\%) distributions. Binding energies are referenced with respect to the adventitious carbon $(\mathrm{C} 1 \mathrm{~s} \mathrm{BE}=284.6 \mathrm{eV})$.

ICP-AES samples were analyzed using a Shimadzu ICPE-9000 instrument with a mini plasma torch in axial reading mode. The sample preparation involves the digestion of the p-Si|ALD-TiO ${ }_{2}^{-}$ $\left|\mathrm{SC}^{-\mathrm{TiO}_{2}}\right| \mathbf{C o}_{\mathbf{C 1 1 P}} \mid \mathrm{ALD}^{-\mathrm{TiO}_{2}}$ electrode $\left(22.5 \mathrm{~cm}^{2}\right.$ area $)$ in $10 \mathrm{~mL}$ of $98 \%$ sulfuric acid at $60{ }^{\circ} \mathrm{C}$ for one hour under sonication. The solution was then diluted to $30 \mathrm{~mL}$ with $1 \%$ ultrapure nitric acid solution prepared with MilliQ water and sonicated for 5 hours. Further, $1.67 \mathrm{~mL}$ of this solution was diluted to $10 \mathrm{~mL}$ with $1 \%$ ultrapure nitric acid prepared with MilliQ water. This final solution $(10 \mathrm{~mL})$ was analyzed for cobalt concentration by ICP-AES. The samples were prepared in triplicate.

\section{Photocurrent and microGC measurements}

Electrochemical analysis was performed using a BioLogic SP300 bipotentiostat and a representative three-electrode setup. A platinum wire was used as the auxiliary electrode and $\mathrm{Ag} / \mathrm{AgCl}$, $\mathrm{KCl}(3 \mathrm{M}$ ) (denoted as $\mathrm{Ag} / \mathrm{AgCl}$ ) as the reference electrode bridged to the electrolyte through a Vycor frit. The unpolished side of silicon was cotton swabbed with an In-Ga eutectic mixture and superposed with a copper plate. The electrical connection was made through the copper plate. Photoelectrodes were front-illuminated with a $300 \mathrm{~W}$ ozone-free xenon lamp (Newport) operated at $280 \mathrm{~W}$ coupled to an AM 1.5 filter. Irradiance at the substrate surface was measured to be $100 \mathrm{~mW} \mathrm{~cm}^{-2}$ using a Newport PM1918-R power meter.

Calibration of the reference electrode was realized with $\left[\mathrm{K}_{4} \mathrm{Fe}(\mathrm{CN})_{6}\right]$ in $0.1 \mathrm{M}$ potassium phosphate buffer at $\mathrm{pH} 7$ (ref. 35) and conversion of potentials against the normal hydrogen electrode (NHE) and the reversible hydrogen electrode (RHE) was performed as previously described. ${ }^{36}$

Fill factor calculation: ${ }^{37}$

$$
\mathrm{FF}=\frac{P_{\max }}{V_{\mathrm{OC}} j_{\mathrm{SC}}}
$$

where $P_{\max }$ is the product of voltage $(\mathrm{V})$ and current (A) at maximum power, $V_{\mathrm{OC}}(\mathrm{V})$ is the open circuit voltage and $j_{\mathrm{SC}}(\mathrm{A})$ is the short circuit current. We normalized the voltage (V) vs. RHE.

A MicroGC S3000 (SRA Instruments) with a diamond LV Ms5A 14m module was operated via a Soprane chrome interface. Throughout the chronoamperometric run, argon gas was purged into the electrolyte at a flow rate of $5 \mathrm{~mL} \mathrm{~min}^{-1}$ controlled with a mass flow controller, and the outlet gas mixture was analyzed using a microGC.

\section{Conflicts of interest}

There are no conflicts to declare.

\section{Acknowledgements}

This work was supported by the French National Research Agency (Labex program ARCANE - ANR-11-LABX-0003-01 and ANR-17-EURE-0003).

\section{References}

1 M. G. Walter, E. L. Warren, J. R. McKone, S. W. Boettcher, Q. Mi, E. A. Santori and N. S. Lewis, Chem. Rev., 2010, 110, 6446-6473.

2 N. Armaroli and V. Balzani, ChemSusChem, 2011, 4, 21-36.

3 N. Armaroli and V. Balzani, Energy Environ. Sci., 2011, 4, 3193-3222.

4 J. R. McKone, N. S. Lewis and H. B. Gray, Chem. Mater., 2014, 26, 407-414.

5 D. Zhang, J. Shi, W. Zi, P. Wang and S. Liu, ChemSusChem, 2017, 10, 4324-4341.

6 J. Gu, Y. Yan, J. L. Young, K. X. Steirer, N. R. Neale and J. A. Turner, Nat. Mater., 2015, 15, 456.

7 A. M. Beiler, D. Khusnutdinova, S. I. Jacob and G. F. Moore, Ind. Eng. Chem. Res., 2016, 55, 5306-5314.

8 D. Khusnutdinova, A. M. Beiler, B. L. Wadsworth, S. I. Jacob and G. F. Moore, Chem. Sci., 2017, 8, 253-259.

9 B. L. Wadsworth, A. M. Beiler, D. Khusnutdinova, S. I. Jacob and G. F. Moore, ACS Catal., 2016, 6, 8048-8057.

10 J. J. Leung, J. Warnan, D. H. Nam, J. Z. Zhang, J. Willkomm and E. Reisner, Chem. Sci., 2017, 8, 5172-5180.

11 S. Chandrasekaran, T. Nann and N. H. Voelcker, Nano Energy, 2015, 17, 308-322.

$12 \mathrm{~S} . \mathrm{Hu}, \mathrm{N}$. S. Lewis, J. W. Ager, J. Yang, J. R. McKone and N. C. Strandwitz, J. Phys. Chem. C, 2015, 119, 2420124228.

13 B. Seger, T. Pedersen, A. B. Laursen, P. C. K. Vesborg, O. Hansen and I. Chorkendorff, J. Am. Chem. Soc., 2013, 135, 1057-1064.

14 Y. W. Chen, J. D. Prange, S. Dühnen, Y. Park, M. Gunji, C. E. D. Chidsey and P. C. McIntyre, Nat. Mater., 2011, 10, 539. 
15 C. C. L. McCrory, S. Jung, I. M. Ferrer, S. M. Chatman, J. C. Peters and T. F. Jaramillo, J. Am. Chem. Soc., 2015, 137, 4347-4357.

16 M. R. Nellist, F. A. Laskowski, F. Lin, T. J. Mills and S. W. Boettcher, Acc. Chem. Res., 2016, 49, 733-740.

17 H. Gerischer, J. Electroanal. Chem. Interfacial Electrochem., 1977, 82, 133-143.

18 F. D. Lin and S. W. Boettcher, Nat. Mater., 2014, 13, 81-86.

19 S. Hennessey and P. Farras, Chem. Commun., 2018, 54, 66626680.

20 N. Coutard, N. Kaeffer and V. Artero, Chem. Commun., 2016, 52, 13728-13748.

21 N. Queyriaux, N. Kaeffer, A. Morozan, M. Chavarot-Kerlidou and V. Artero, J. Photochem. Photobiol., C, 2015, 25, 90-105.

22 E. S. Andreiadis, P. A. Jacques, P. D. Tran, A. Leyris, M. Chavarot-Kerlidou, B. Jousselme, M. Matheron, J. Pecaut, S. Palacin, M. Fontecave and V. Artero, Nat. Chem., 2013, 5, 48-53.

23 N. Kaeffer, M. Chavarot-Kerlidou and V. Artero, Acc. Chem. Res., 2015, 48, 1286-1295.

24 S. Donck, J. Fize, E. Gravel, E. Doris and V. Artero, Chem. Commun., 2016, 52, 11783-11786.

25 N. M. Muresan, J. Willkomm, D. Mersch, Y. Vaynzof and E. Reisner, Angew. Chem., Int. Ed., 2012, 51, 12749-12753.

26 N. Kaeffer, C. D. Windle, R. Brisse, C. Gablin, D. Léonard, B. Jousselme, M. Chavarot-Kerlidou and V. Artero, Chem. Sci., 2018, 9, 6721-6738.
27 S. P. Pujari, L. Scheres, A. T. M. Marcelis and H. Zuilhof, Angew. Chem., Int. Ed., 2014, 53, 6322-6356.

28 A. M. Lapides, B. D. Sherman, M. K. Brennaman, C. J. Dares, K. R. Skinner, J. L. Templeton and T. J. Meyer, Chem. Sci., 2015, 6, 6398-6406.

29 P. E. Rutherford and D. A. Thornton, Spectrochim. Acta, Part A, 1979, 35, 711-714.

30 H. Jensen, A. Soloviev, Z. Li and E. G. Søgaard, Appl. Surf. Sci., 2005, 246, 239-249.

31 A. Litke, Y. Su, I. Tranca, T. Weber, E. J. M. Hensen and J. P. Hofmann, J. Phys. Chem. C, 2017, 121, 7514-7524.

32 See Fig. S3† for control data on electrodes lacking the $\mathbf{C o}_{\mathbf{C 1 1}}$ catalyst or containing decyl phosphonic acid $\left(\mathbf{C}_{\mathbf{1 0 p}}\right)$.

33 S. Cobo, J. Heidkamp, P.-A. Jacques, J. Fize, V. Fourmond, L. Guetaz, B. Jousselme, V. Ivanova, H. Dau, S. Palacin, M. Fontecave and V. Artero, Nat. Mater., 2012, 11, 802-807. 34 D. H. Nam, J. Z. Zhang, V. Andrei, N. Kornienko, N. Heidary, A. Wagner, K. Nakanishi, K. P. Sokol, B. Slater, I. Zebger, S. Hofmann, J. C. Fontecilla-Camps, C. B. Park and E. Reisner, Angew. Chem., Int. Ed., 2018, 57, 10595-10599.

35 J. E. O'Reilly, Biochim. Biophys. Acta, 1973, 292, 509-515.

36 N. Kaeffer, J. Massin, C. Lebrun, O. Renault, M. ChavarotKerlidou and V. Artero, J. Am. Chem. Soc., 2016, 138, 12308-12311.

37 D. Bartesaghi, I. D. Perez, J. Kniepert, S. Roland, M. Turbiez, D. Neher and L. J. A. Koster, Nat. Commun., 2015, 6, 7083. 